\title{
SYSTEM DOCUMENTATION AS BASIS FOR COMPANY BUSINESS PROCESS IMPROVEMENT
}

\author{
Dewan Pelawi \\ Information Systems Department, School of Information Systems, \\ Bina Nusantara University Jl. K. H. Syahdan No. 9, Jakarta 11480, Indonesia \\ dewanpelawi2318@binus.ac.id, dewanpelawi@yahoo.com
}

\begin{abstract}
Business process is an activity performed together to achieve business goals. Good business process will support the achievement of the organization's plan to make profit for the company. In order to understand the business process, the business process needs to be documented and analyzed. The purpose of research is to make the system documentation as a basis to improve or complete the ongoing business process. The research method is system documentation. System documentation is a way to describe the operation of the system. System documentation consists of variety of forms depending on the needs of the system, which wish to be portrayed. The expected result is system documentation in the form of the proposed DFD and business process improvement. The obtained conclusions show that by doing system documentation will provide basic improvements to a better business process by analyzing the relationship between the process with another process, through the data, which are used together.
\end{abstract}

Keywords: systems; documentation; system documentation; DFD

\section{INTRODUCTION}

The needs of making business decisions demand the availability of information for the decision maker. Information derived from parts of organization that does its functions to achieve the organization's goals. In doing business functions it must perform business activities. The activity of doing the business functions refers as business processes. Business processes is defined as the activities that are done together to achieve business goals [1]. Business processes in every part of the organization is different from one another. Business processes needs data as results. To help making the business processes faster, well-structured, and more effective it can be supported by information system.

Every part of the organization is one unit that cannot be separated. To achieve the organization's goals, each part of the organization must be cooperated and helping each other. The unity of organization unit is related by shared data [2]. The needs of exchange data demand the relation of communication in one section to other sections. The problem appears if a data concept between one section with others is not same even though referring in the same data. The movement of business process from one section to other sections is not same, so it creates time to exchange information or the needed data. One way to adapt all business processes in a company is by making system documentation.
System documentation is a way to describe operational system. The documentation consists of various types depend on the perspective of documented systems. When preparing the system documentation, the activity creates system documentation for answering questions about who involves in the activity, what activity happens, where the activity takes place, why the activity happens.

One type of system documentation is data flow diagram (DFD). Data flow diagram illustrates data flow in the system and has three types which are context diagram, level 0 diagram and level 1 diagram [3]. Context diagram gives an illustration between system with external entity that provides input or output from system and system interest. System interest is a system or process that focuses on documentation. System interest will clarify the limit of the system.

Physical DFD provides detail entity that involved on process and data flow among entity and its interaction with external entities. Logical DFD depicts the process on system, the data flow among the processes and how the processes interact with external entities that provide input for system or receive output from system; system interest.

\section{Entity}

Before reading the documentation system, it is important to understand what is available and what 
part of system documentation. Entity is a part of business processes or systems. Entity refers to people and anything that part of the systems. An entity can be person or anything that involves in business process activities. Entity can be categorized as internal or external [4].

The difference between internal and external depends on the documented process and the function and the duties done by entity. Entity concept is also used for preparing database. In context system documentation, an entity is a person or thing that involve in execution process. An entity will be seen in system documentation likewise in database. External entities are all entities that provide input towards process or receive output from a process. An external entity does not use data towards process but external entity provides or sends data.

This is why documentation process is important because entity can be internal or external for one process but different for other processes. The obvious difference between internal entity and external entity is internal entity is defined as an entity that processing or changing data in certain business process; referring to data usage.

The processing or changing data is not only sending or receiving data, but also using data for certain duties and needs in documenting business process. Several keywords for determining if the data is processed or changed in process are including reviews, confirms, reconciles, data entry, approves, batches, calculates, authorities, compares, annotates, prepares, records, sorts and matches. Verb identifies that the activity is more than sending and receiving data. Verb gives meaning that the data is being used.

\section{Narration}

The starting point of business documentation is its narrative structure. Narrative structure is written in the description of how the process works. Generally the narrative structure will be prepared after observation process in operation and after interview with participant lock in the process. After observing and interviewing, the accountant will prepare the written description from the operation process. The advantages of narrative structure are accessible and anyone can read it. It can make narrative structure becomes popular documentation process. However it will be different if it is in deeper analysis and better comprehension process, the narrative structure is limited subject.

\section{Narrative Structure Table}

The purpose of Narrative Structure Table is to summarize in systematic form to emphasize who put involve in process, what process is used, what activity that happens in process and the purpose of out that is produced during the done several process. Structure table is as below:
Table 1. Narration Table

\begin{tabular}{llll}
\hline No Entity & Input & Process/Activity Output
\end{tabular}

\section{Data Flow Diagram}

Data Flow Diagram is a form of system documentation, which depicts the systems and components that built a system, along with the data flow among the components. Data flow diagram enables user of documentation to identify entities that involved among entities; processes that happened in system and data flow between entity and business processes. There are three types of DFD which are a context diagram, a physical DFD and a logical DFD.

Context diagram is the simplest; it only depicts what is done by system to the user. Physical DFD identifies person, place, and thing that doing process (internal entity) also to show who get involved in system. Logical DFD shows the done process in system. Besides identifying, logical DFD shows what takes part of system that depicts main process. Physical DFD focuses on entities that are done the activities meanwhile logical DFD focuses on logical activities and process that occur. Symbols for DFD are shown below:

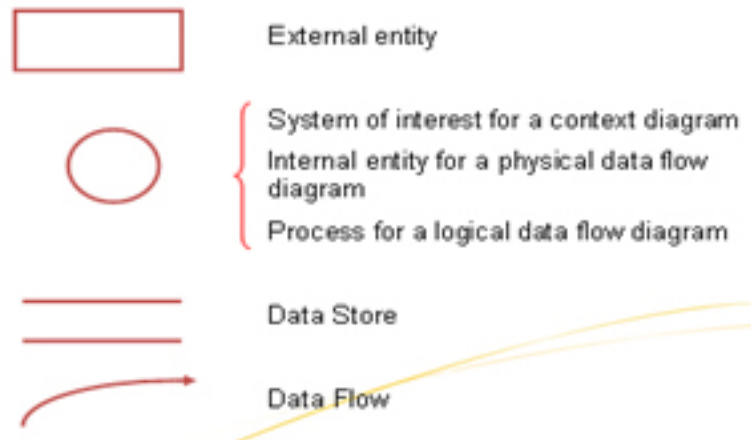

Fig 1: Symbols from Data Flow Diagram

\section{Context Diagram}

Context Diagram provides system illustration and entities that give input to system or receive output from system. Context diagram depicts data flow toward system without showing process.

\section{Detailed Diagram}

Context diagram is divided into level0diagram, level 1, and so on. On detailed diagram also determines data store will save the data and also give information data to process. External entity should not connect directly with external entity. 


\section{Relation between System Documentation with Repairing Business Process}

Some ways for repairing business process are understanding how business process works, identifying all activities, finding anyone who involves in the business process, relation between one section to other sections in the entire organization and data flow that is used together in the business process. A deep analysis needs the ability to understand the business process. One way to understand the business process is by analyzing system documentation. System documentation gives sequence illustration of business process. DFD with detailed diagram will show the main key of the activity and the needed data to do the process and who involves in the process.

Analysis of the documentation process is part of the process of engineering to find the processes that is done in parallel, where the data used are always the same so it can be eliminated and the same activities done several times with the same data and the rest of collection of the same data can be removed. All this activities give the improvement of the business process, which can only be done by understanding the system documentation.

\section{METHOD}

Four steps of system documentation will be applied in this research. The first step is describing business process with the narration and arranging it in narrative structure table. The starting point of arranging the narrative structure table is by making entities list that involve in the process. The entities list will help in clarifying what really happens in the system. In preparing the narrative structure table it must be concerned about special activities that happen and the sequence. The more precisely these activities sorted the more clearly the system of documentation produced.

The second step is drawing system documentation by making a context diagram, detailed diagram consisting of level 0 and level 1 . Some ways to draw a context diagram are first: identify a system that involved, draw a great circle to show the system involved; second: identify external entity that is not showing the activities of information processing; draw it in rectangular form; third: identify all the data flow between entities and external system; fourth: describe the data flow that is connected with external entity and the system involved and write the data. Then drawing logical DFD; the first thing to do in drawing logical DFD are determining information process activity; creating table, which all business processes are well ordered; then determining the related activities, next is logically grouping the activities.

The third step is understanding and analyzing the exist DFD to find improvement suggestion towards the business process.
The fourth step is suggesting business process improvement.

\section{RESULT AND DISCUSSION}

PD Gerak Tani is a small to medium enterprise that deals in production field and seasoning sales. Gerak Tani was built on May 2, 1977, was developed by Drs. N.J. Sembiring. Milled chili and seasoning Gerak Tani were firstly marketed at Rumput Market, Manggarai South Jakarta named "Sembiring" milled chili and seasoning. Nowadays it changes into "GerakTani" milled chili and seasoning; it has been marketed broadly surrounding Jabodetabek and can be found in markets and also supermarkets in Bekasi.PD GerakTani has had certificates of UU Interference, TDI, halal, SIUP, Brand Rights, PIRT, SNI, Patent Rights, and member of Kadin Jaya. The produced products are milled chili that is divided into smooth flat chili and smooth salty chili, cream milled seasoning like pepper, nutmeg, cinnamon, coriander, cumin, dried flavor, and various of "Gerak Tani" dried seasoning like rendang, opor, curry, Semur, grilled chicken, fried chicken, fish pepes, soto, arsik, sweet sour, pecel, Bali seasoning, sambalado, fried chili, kalio, rica-rica, pangek, curry fish, grilled fish, pesmol, empal, steak, pinapple pacri, malbi, lodeh vegetables, sour vegetables, rhombus vegetables, chicken porridge, kebuli rice, fried rice, seasoning of rujak, etc.

GerakTani produces ready to use seasoning in cream or pasta, milled chili and seasoning (powder). The advantages of GerakTani products are used no MSG and preservation is done by collaborating with Patir Batan using irradiation with gamma ray. Production process is started with sorting good raw materials, then continue by using three steps of cleaning which are first: with machine; second: packing into big basin and third: dipping to boiled water, after the raw material is clean it continues with mixing, then packaging, and irradiation/gamma ray then stored and ready to be marketed. The durability of bottle and plastic package products are one year and can be more in low temperature.

Packaging is done in three ways which are (1) Pasteurization: packaging seasoning in hot temperature (80-90 Celsius degree). (2) Directly dip into ice water. (3) Vacuum: using vacuum packing machine, that laboratory test collaborating with National Nuclear Energy, POM, IPB, etc.

The markets are restaurant, catering including ACS-Garuda, traditional market, and supermarket. The outline of production process consists of six important stages, which are sorting the raw material, washing, balancing, trituration, packing, irradiation before it sends to storage. Now Gerak Tani markets 0,5 ton per day, the capacity of Gerak Tani production gains 1 ton per day, the total of labor is 25 persons, the processed commodity about 50 types. 


\section{First stage: Business Process}

Business process in PD Gerak Tani centered in located factory that is controlled by leader of UD Gerak Tani is helped by 3 secretaries. Sales activity is done through marketing outlet that located at Kramat Jati market, East Jakarta and through collaboration with stores like Carrefour, Naga supermarket, etc. Employees in the outlet report the sales revenue to the leader. If there are the needs to do purchasing, the employee will call the office to report it or the needs of product in warehouse. Furthermore if there is order that is done through outlet will be continued to office to be followed by secretary. All activities and schedules of employees are determined and recorded by secretary.

Every day before the end of working hours, the working activity from all employees will be recorded. Production section does its activity based on the instruction from the leader through the secretary. Receiving things like raw material will be reported to secretary and the outflowof goods like the result of product is also based on office's instruction. The creation of goods is also done from office by contacting the supplier according to the needs. Then the supplier will send the goods to the factory and directly gives the invoice. The need of raw material, which is not supplied by the supplier, is directly buy at Kramat Jati market. The secretary will make notes about the wished needed things then ask the driver to do the purchasing. As regular customer, the driver only needs to visit the seller who will prepare the company's needs. If the goods are not suitable with the standard, it will be return.

From the business process in UG GerakTani, the need of data is as follow:

Table 2: Business Process in UD Gerak Tani

\begin{tabular}{|c|c|c|c|c|}
\hline No & Business Function & Input & Business Process & Output \\
\hline 1 & Production & $\begin{array}{l}\text { Order, Raw-material, } \\
\text { Production schedule }\end{array}$ & $\begin{array}{l}\text { 1. The demand of production from } \\
\text { administration } \\
\text { 2. The usage of raw-material for } \\
\text { production } \\
\text { 3. Producing }\end{array}$ & Product \\
\hline 2 & Selling & Demand, Outgoing goods & $\begin{array}{l}\text { 1. The request of goods demand to } \\
\text { administration } \\
\text { 2. Outgoing goods from warehouse to } \\
\text { fulfill customers' needs. }\end{array}$ & Product \\
\hline 3 & Warehouse & $\begin{array}{l}\text { Reception, Outflow of goods, } \\
\text { Receiving goods, Purchasing }\end{array}$ & $\begin{array}{l}\text { 1. Receiving raw-material } \\
\text { 2. Outflow of goods } \\
\text { 3. Receiving goods after production } \\
\text { 4. The request of purchasing demand } \\
\text { of raw-material to administration }\end{array}$ & $\begin{array}{l}\text { Reception, } \\
\text { Outflow of goods, } \\
\text { Product, } \\
\text { Demand of raw-material }\end{array}$ \\
\hline 4 & Administration & $\begin{array}{l}\text { Selling, Payment, PO, } \\
\text { Production schedule }\end{array}$ & $\begin{array}{l}\text { 1. Posting all selling transaction } \\
\text { 2. Posting all purchasing transaction } \\
\text { 3. Requesting the goods demand to } \\
\text { supplier } \\
\text { 4. Ordering production to production } \\
\text { section } \\
\text { 5. Ordering outflow of goods from } \\
\text { warehouse } \\
\text { 6. Receiving goods report from } \\
\text { warehouse } \\
\text { 7. Receiving outflow of goods report } \\
\text { from warehouse } \\
\text { 8. Receiving the raw material usage } \\
\text { from warehouse } \\
\text { 9. Receiving production report from } \\
\text { production section } \\
\text { 10. Payment } \\
\text { 11. Purchasing raw material }\end{array}$ & $\begin{array}{l}\text { Selling, Purchasing, } \\
\text { production, Outflow of } \\
\text { goods }\end{array}$ \\
\hline
\end{tabular}


Second Stage: Draw Context Diagram, Level 0 Diagram and Level 1 Diagram

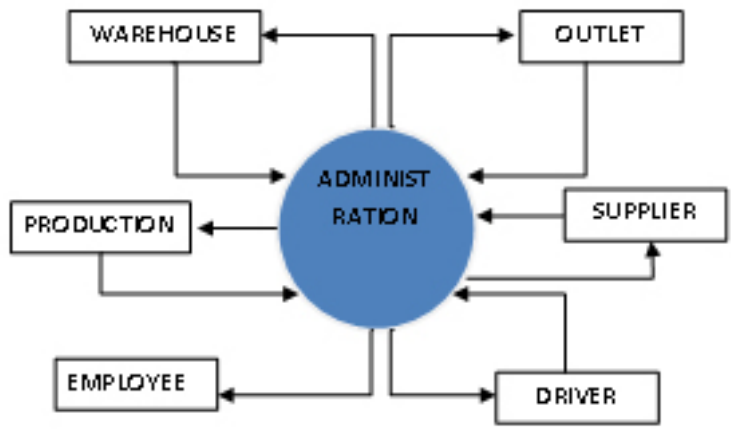

Fig 2: Context Diagram

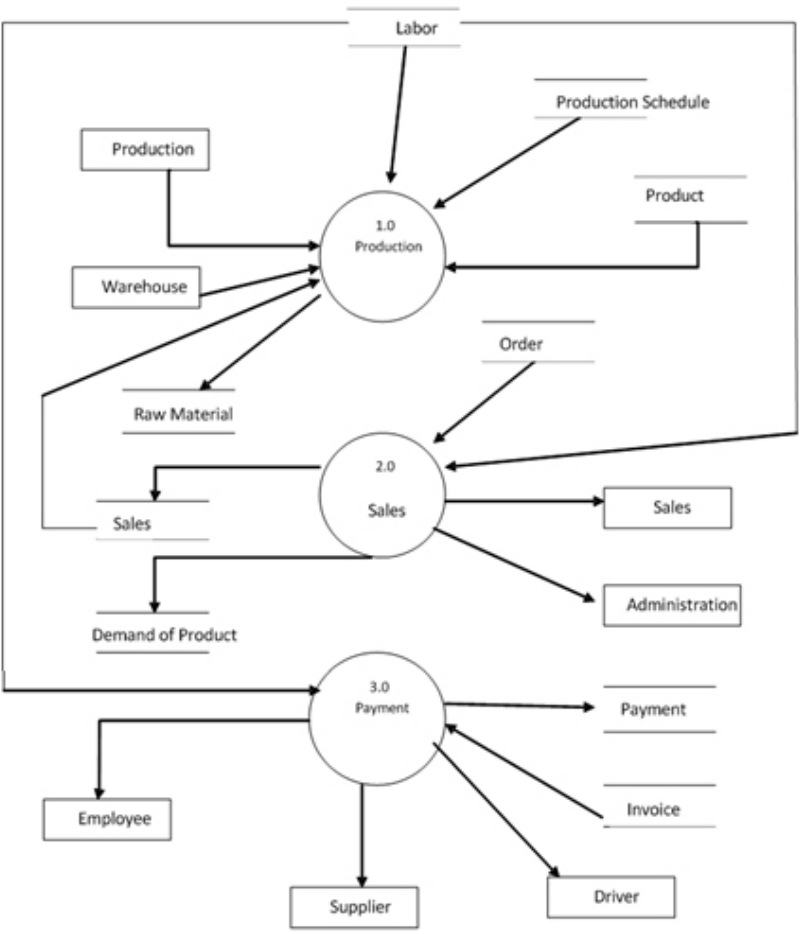

Fig 3: level 0 Diagram

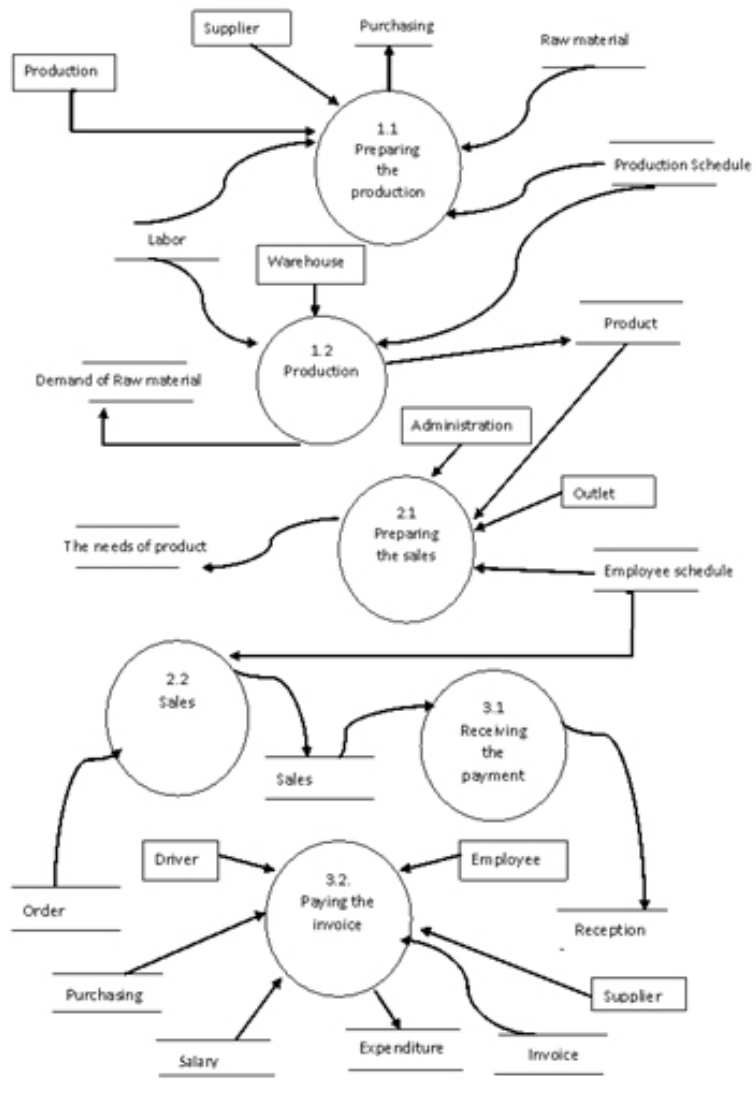

Fig 4: level 1 Diagram

Third Stage: Understanding and Analyzing DFD

Based on the analysis of DFD, it can be concluded that all activities tend to be centered and based on the administration section. Administration performs all business processes or company operational so it can control all company activities. It causes no maximum working, where production section only does what it has been asked to do, the creation of goods depends on the needs from the demand from production section and sales section and the purchasing is still done by the driver. Administration section covers several positions; noting employee's working hours, paying the salary, paying the invoice, buying raw material outside the supplier, receiving order from customer, scheduling the driver, and many more.

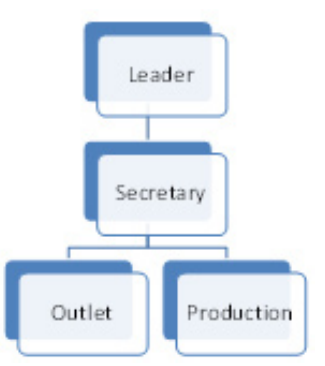

Fig 5: Understanding and Analyzing DFD 


\section{Fourth Stage: Suggest Improvement \\ for Business Process}

Generally there are three main processes in company. The processes are income process, expenditure process, production process. Apart from those, the process also supports with personnel process and salary and also bookkeeping or general ledger and finance report. To fix the business process, it is suggested to make a clear organizational structure. The suggested structure is as follow:

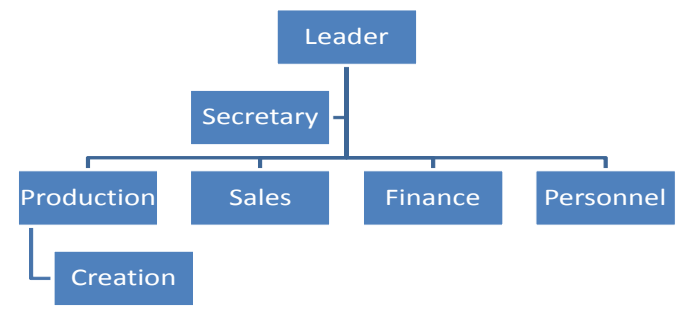

Fig 6: Organizational Structure

From the suggested structure, each division is suitable with its business function. This division is hoped to make a better business process because there is no overlap of responsibility in finishing the job.

\section{CONCLUSION}

System documentation takes important part in organization; giving organization the note of business process. System documentation uses narration table and DFD. Narrative structure depicts the system in text. Context diagram depicts system with external entity that interacts by giving input and receiving output towards the system. Level 0 diagram and Level 1 explain the flow of business process and data. Analysis of DFD gives suggestions to improve the business process by suggesting a new organizational structure.

\section{REFERENCES}

[1] B. Considine, A. Parker, K. Olesen, Y. Blount, D. Speer, Accounting Information Systems: understanding business process, 4th Ed., Australia: John Wiley \& Sons, Ltd., ISBN: 978-0-730-30247-6, 2012

[2] M. Bradford, S. B. Richtermeyer, D. F. Roberts, System Diagramming Techniques: An Analysis of Methods Used in Accounting Education and Practice, Journal of Information Systems, vol. 21, no. 1, pp. 173-212, 2007.

[3] D. C. Ivancevich, R. S. Sawyer, Flowcharting Basics for Internal Auditors. Internal Auditing, vol. 19, no. 5, pp. 26-31, 2004.

[4] S. G. Sutton, The Changing Face of Accounting in an Information Technology Dominated World, International journal of accounting information systems, vol. 1, no. 1, pp. 1-8, 2000. 